\title{
Infrared brazing of Ti-6AI-4V using the Ti-15Cu-15Ni braze alloy
}

\author{
C.-T. CHANG \\ Department of Materials Science and Engineering, National Dong Hwa University, Hualien 974, Taiwan
}

R.-K. SHIUE*

Department of Materials Science and Engineering, National Taiwan University, Taipei 106, Taiwan

E-mail: rkshiue@ntu.edu.tw

Published online: 3 February 2006

Titanium and its alloys are relatively new engineering metals because they have been used as structural materials only since 1952 [1]. Ti-6Al-4V is by far the most important and widely used titanium alloy, accounting for $60 \%$ of the titanium market in 1989 . It can be readily welded, forged and machined [1]. However, the welding of Ti alloys may be not appropriate for all applications such as titanium honeycomb sandwich structure [2]. In such a case, brazing is a better way to join the titanium alloy. However, selection of filler metals used in brazing titanium alloys is critical to avoid the formation of undesirable intermetallics [2]. Ti- $15 \mathrm{Cu}-15 \mathrm{Ni}$ in weight percent is a successful commercially available brazing filler metal which can braze titanium and its alloys [2-4]. Ti- $15 \mathrm{Cu}-$ $15 \mathrm{Ni}$ can be used at temperatures up to $870{ }^{\circ} \mathrm{C}$, and it is used in this study.

Infrared brazing is featured with a very high heating rate of up to $3000^{\circ} \mathrm{C} / \mathrm{min}$, and many successful joints have been made by infrared brazing [5-10]. Accordingly, it is a novel technique applied in brazing many structural alloys. The purpose of this research is focused on vacuum brazing including traditional furnace brazing and infrared brazing Ti-6Al-4V alloy using the Ti-15Cu-15Ni filler metal. The wetting angle measurement, microstructural evolution, and shear strength of the brazed joint are extensively assessed in the experiment.

Ti-6Al-4V plate with the dimension of $10 \times 10 \times 3 \mathrm{~mm}$ was used in the experiment. The substrate was polished by $\mathrm{SiC}$ papers up to 1200 grits, and subsequently cleaned using an ultrasonic bath with acetone as the solvent prior to brazing. Ticuni ${ }^{\circledR}$ foil purchased from Wesgo, Inc. was used as the brazing filler metal. Its nominal composition is $15 \% \mathrm{Cu}, 15 \% \mathrm{Ni}$ and Ti balance. The dimensions of Ticuni ${ }^{\circledR}$ foil are $100 \mathrm{~mm}$ width and $50 \mu \mathrm{m}$ thickness. The solidus and liquidus temperatures of the Ticuni ${ }^{\circledR}$ foil are 910 and $960^{\circ} \mathrm{C}$, respectively.
The dynamic wetting angle measurements were performed using a traditional vacuum furnace at 970 and $1000^{\circ} \mathrm{C}$ for $0-2400 \mathrm{~s}$, respectively $[5,7,9]$. The heating rate of the furnace was maintained at $30^{\circ} \mathrm{C} / \mathrm{min}$. The braze alloy with near spherical shape used in the wetting angle test was prepared from Ticuni ${ }^{\circledR}$ foil by vacuum arc remelting (VAR) with the operation voltage of $60 \mathrm{~V}$ and at 130-150 A. The weight of each spherical ball was approximately $0.12 \mathrm{~g}$, and it was placed on Ti-6Al-4V substrate in the test. The image of the molten braze on the substrate was recorded simultaneously with a digital camera.

Infrared brazing was performed in a vacuum of $5 \times 10^{-5}$ mbar at $970,1000,1030$, and $1060^{\circ} \mathrm{C}$ for 180 and $300 \mathrm{~s}$, respectively. Its heating rate was set at $600^{\circ} \mathrm{C} / \mathrm{min}$ throughout the experiment. Furnace brazing was performed in a vacuum of $5 \times 10^{-5} \mathrm{mbar}$ at $970^{\circ} \mathrm{C}$ for 1200 and $1800 \mathrm{~s}$. The heating rate of furnace brazing was kept at $30^{\circ} \mathrm{C} / \mathrm{min}$. Additionally, all furnace-brazed specimens were preheated at $600^{\circ} \mathrm{C}$ for $600 \mathrm{~s}$ prior to the brazing temperature.

The brazed specimen was sectioned with a diamond saw, and subsequently experienced a standard metallo-

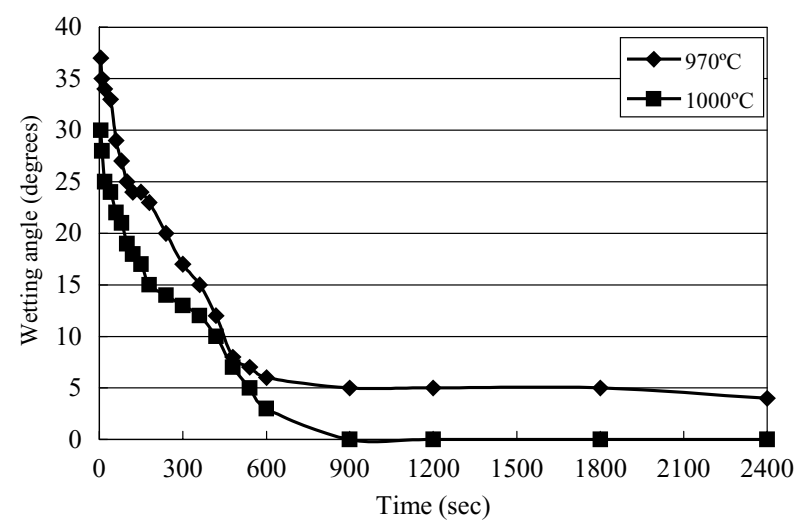

Figure 1 Dynamic wetting angle measurements of Ti-15Cu-15Ni on the Ti-6Al-4V substrate at 970 and $1000^{\circ} \mathrm{C}$ between 0 and $2400 \mathrm{~s}$.

* Author to whom all correspondence should be addressed. 
graphic procedure prior to further inspection. The etching solution was $3 \mathrm{ml} \mathrm{HF}+6 \mathrm{ml} \mathrm{HNO} 3+100 \mathrm{ml}$ water. The cross section of the brazed specimens was examined using a Hitachi $3500 \mathrm{H}$ scanning electron microscope (SEM) equipped with an energy-dispersive spectrometer (EDS) for chemical analyses. Its operational voltage was kept at $20 \mathrm{kV}$, and spot size was approximately $1 \mu \mathrm{m}$.
The shear test was performed in order to evaluate the bonding strength of the brazed specimen. A Shimadzu AG-10 universal testing machine with a constant crosshead speed of $0.5 \mathrm{~mm} / \mathrm{min}$ compressed the brazed specimen $[8,10]$. Both the SEM cross-section image and fractographs of the brazed joint after shear test were examined in the experiment.
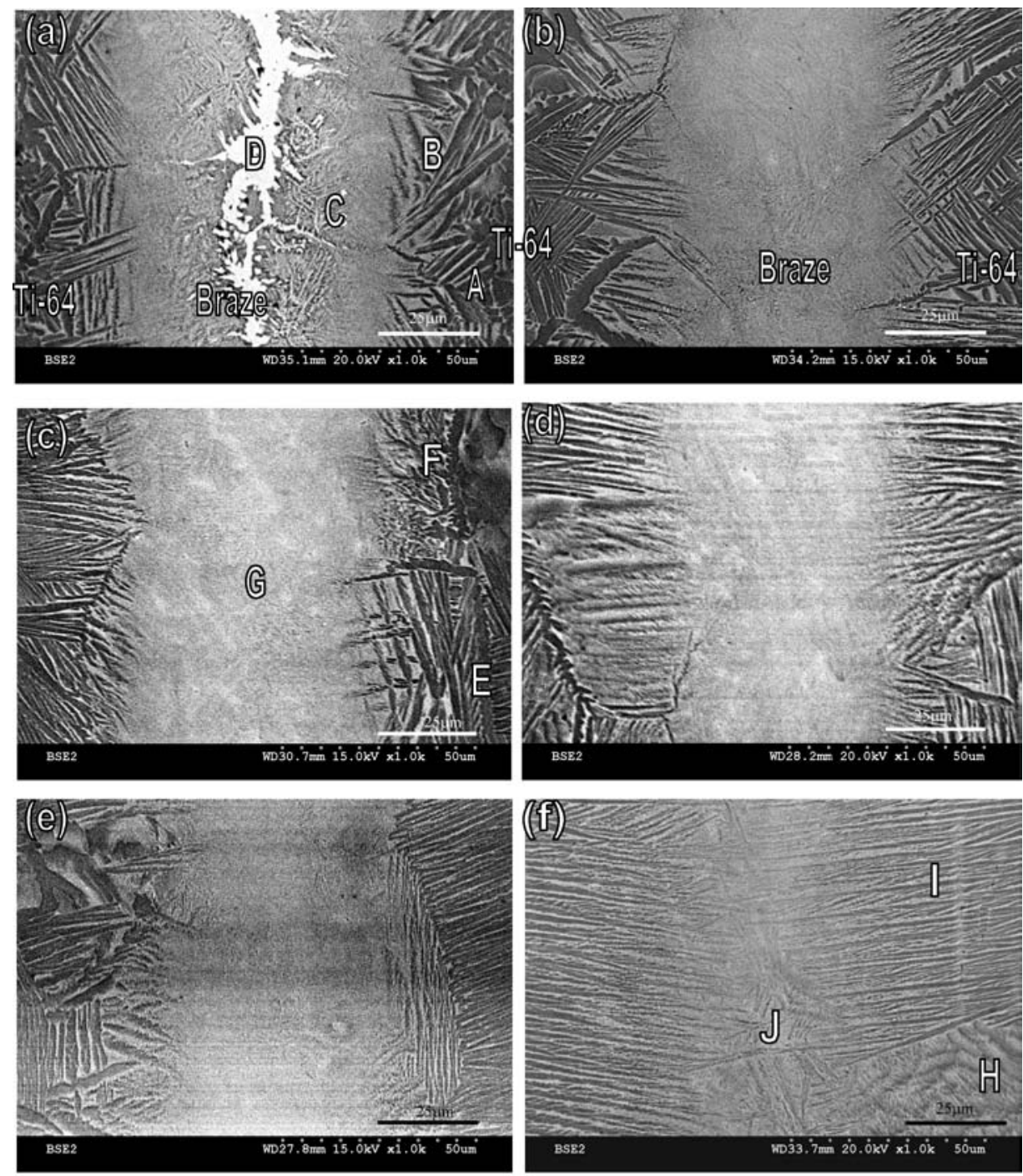

\begin{tabular}{cccccc}
\hline Location & $\mathrm{Al}$ & $\mathrm{Cu}$ & $\mathrm{Ni}$ & $\mathrm{Ti}$ & $\mathrm{V}$ \\
\hline $\mathrm{A}$ & 6.3 & 2.2 & 3.0 & 85.1 & 3.4 \\
$\mathrm{~B}$ & 4.8 & 4.9 & 6.1 & 80.9 & 3.4 \\
$\mathrm{C}$ & 3.7 & 7.5 & 6.5 & 80.3 & 2.0 \\
$\mathrm{D}$ & 1.8 & 11.5 & 10.0 & 75.7 & 1.1 \\
$\mathrm{E}$ & 6.2 & 1.3 & 2.7 & 86.6 & 3.2 \\
$\mathrm{~F}$ & 5.2 & 4.7 & 3.8 & 83.9 & 2.4 \\
$\mathrm{G}$ & 2.9 & 9.2 & 7.2 & 79.3 & 1.5 \\
$\mathrm{H}$ & 6.6 & 3.1 & 3.0 & 85.3 & 2.0 \\
$\mathrm{I}$ & 7.9 & 3.1 & 3.4 & 82.9 & 2.7 \\
$\mathrm{~J}$ & 6.5 & 3.5 & 2.9 & 85.1 & 2.0 \\
\hline
\end{tabular}

Figure 2 The SEM BEIs and EDS chemical analyses in at.\% of infrared brazed joints with various brazing conditions: (a) $970^{\circ} \mathrm{C}, 180 \mathrm{~s}$; (b) $970^{\circ} \mathrm{C}, 300 \mathrm{~s}$; (c) $1000^{\circ} \mathrm{C}, 180 \mathrm{~s}$; (d) $1000^{\circ} \mathrm{C}, 300 \mathrm{~s}$; (e) $1030^{\circ} \mathrm{C}, 300 \mathrm{~s}$; (f) $1060^{\circ} \mathrm{C}, 300 \mathrm{~s}$. 
Fig. 1 shows dynamic wetting angle measurements of Ti- $15 \mathrm{Cu}-15 \mathrm{Ni}$ on the Ti-6Al-4V substrate. According to the figure, the molten braze alloy can effectively wet the Ti-6Al-4V substrate at $970^{\circ} \mathrm{C}$. If the brazing temperature is increased to $1000^{\circ} \mathrm{C}$, complete spreading of the molten braze on the substrate is easily achieved in $900 \mathrm{~s}$.

Fig. 2 illustrates the SEM backscattered electron images (BEIs) and EDS chemical analyses of infrared brazed joints with various brazing conditions. Based on the EDS analyses, the infrared brazed joint is mainly comprised of the Ti-rich phase alloyed with various amounts of $\mathrm{Al}$, $\mathrm{Cu}, \mathrm{Ni}$, and $\mathrm{V}$. The chemical composition of Ti- $6 \mathrm{Al}-4 \mathrm{~V}$ is $86.2 \% \mathrm{Ti}, 10.2 \% \mathrm{Al}$ and $3.6 \% \mathrm{~V}$, and the chemical composition of $\mathrm{Ti}-15 \mathrm{Cu}-15 \mathrm{Ni}$ braze is $74.8 \% \mathrm{Ti}, 12.1 \% \mathrm{Cu}$ and $13.1 \% \mathrm{Ni}$. For the specimen infrared brazed at $970^{\circ} \mathrm{C}$ for $180 \mathrm{~s}$, the Ti-6Al-4V substrate is alloyed with minor $\mathrm{Cu}$ and $\mathrm{Ni}$ as marked by A and B in Fig. 2. Additionally, the amount of $\mathrm{Cu}$ and $\mathrm{Ni}$ is increased with increasing distance from Ti-6Al-4V substrate to the center of braze. The presence of phase $\mathrm{D}$ with the highest $\mathrm{Cu}$ and $\mathrm{Ni}$ contents resulted from the rapid infrared brazing cycle, because the chemical composition of phase D (Fig. 2a) is very close to that of Ti-15Cu-15Ni braze alloy. The transient phase D disappeared with increase in the brazing temperature and/or time as demonstrated in Fig. 2.

According to related binary alloy phase diagrams, the $\beta$-Ti is completely soluble with $\mathrm{V}$ during infrared brazing [11]. The solubility of $\mathrm{Al}$ in Ti exceeds 11 at.\% at $500^{\circ} \mathrm{C}$. The $\beta$-Ti can dissolve $\mathrm{Cu}$ and $\mathrm{Ni}$ up to 11 and 13 at.\%, respectively [11]. Consequently, $\mathrm{Al}, \mathrm{Cu}, \mathrm{Ni}$, and $\mathrm{V}$ are all dissolved into the Ti matrix at the brazing tem- perature, and the Ti-rich phase is observed as illustrated in Fig. 2. Since Ti is a highly reactive element, it preferentially reacts with many other elements. To avoid the formation of interfacial brittle intermetallic compound(s) in the joint is usually the major concern in brazing most of the titanium alloys. It is noted that there is no obvious interfacial reaction layer observed in the brazed joint. Based on this information, Ti- $15 \mathrm{Cu}-15 \mathrm{Ni}$ braze alloy is very suitable in brazing the Ti-6Al-4V alloy. Both dissolution of the $\mathrm{Ti}$ substrate into the molten braze and diffusive transport of $\mathrm{Cu}$ and $\mathrm{Ni}$ into the substrate are greatly enhanced with increase in the brazing temperature and/or time. Consequently, the Ti-6Al-4V substrate can be readily wetted by the molten braze alloy as displayed in the Fig. 1.

Fig. 3 illustrates the liquidus projection of the $\mathrm{Cu}-\mathrm{Ni}$ Ti ternary alloy phase diagram in atomic percent, and the chemical composition of $\mathrm{Ti}-15 \mathrm{Cu}-15 \mathrm{Ni}$ braze alloy is marked by $\mathrm{A}$ in the figure [12]. It is expected that the chemical composition of the initial molten braze (marked by point A in Fig. 3) will move towards the Ti during infrared brazing due to both dissolution of the substrate and depletion of $\mathrm{Cu}$ as well as $\mathrm{Ni}$ from the molten braze. Accordingly, the infrared brazed joint primarily consists of the Ti-rich phase as shown in Fig. 2.

Fig. 4 displays the SEM images and EDS chemical analysis results of furnace brazed specimens at $970^{\circ} \mathrm{C}$ for 1200 and 1800 s. Similar to the aforementioned result, the Ti-rich phase dominates the furnace brazed joint. Additionally, both platelike $\alpha$-Ti and eutectoid microstruc-

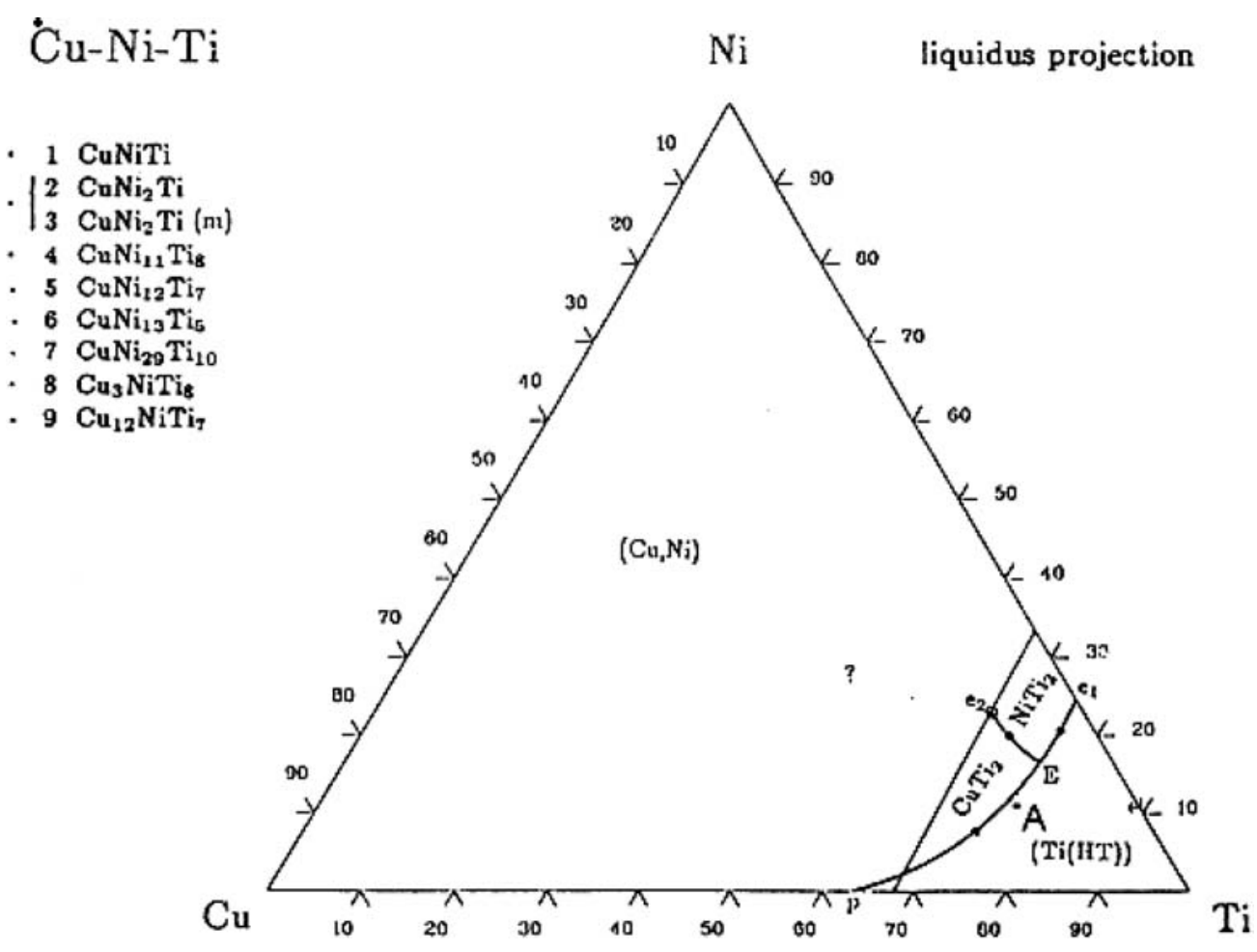

Figure 3 Liquidus projection of the Cu-Ni-Ti ternary alloy phase diagram [12]. 
TAB LE I Shear strengths of various brazed specimens

\begin{tabular}{|c|c|c|c|c|c|c|}
\hline $\begin{array}{l}\text { Braze alloy } \\
\text { (wt.\%) }\end{array}$ & Brazing type & Temperature $\left({ }^{\circ} \mathrm{C}\right)$ & Time (s) & Shear strength (MPa) & $\begin{array}{l}\text { Average shear } \\
\text { strength (MPa) }\end{array}$ & $\begin{array}{l}\text { Standard } \\
\text { deviation (MPa) }\end{array}$ \\
\hline \multirow{10}{*}{$\mathrm{Ti}-15 \mathrm{Cu}-15 \mathrm{Ni}$} & Furnace & 970 & 1200 & 234 & 223 & 10.9 \\
\hline & & & 1200 & 212 & & \\
\hline & Infrared & 970 & 180 & 282 & 284 & 1.6 \\
\hline & & & 180 & 285 & & \\
\hline & Infrared & 1000 & 180 & 258 & 249 & 9 \\
\hline & & & 180 & 240 & & \\
\hline & Infrared & 1030 & 180 & \multirow{2}{*}{\multicolumn{3}{|c|}{ Fracture of Ti-6Al-4V substrate }} \\
\hline & & & 180 & & & \\
\hline & Infrared & 1060 & 180 & \multicolumn{3}{|c|}{ Fracture of Ti-6Al-4V substrate } \\
\hline & & & 180 & & & \\
\hline
\end{tabular}
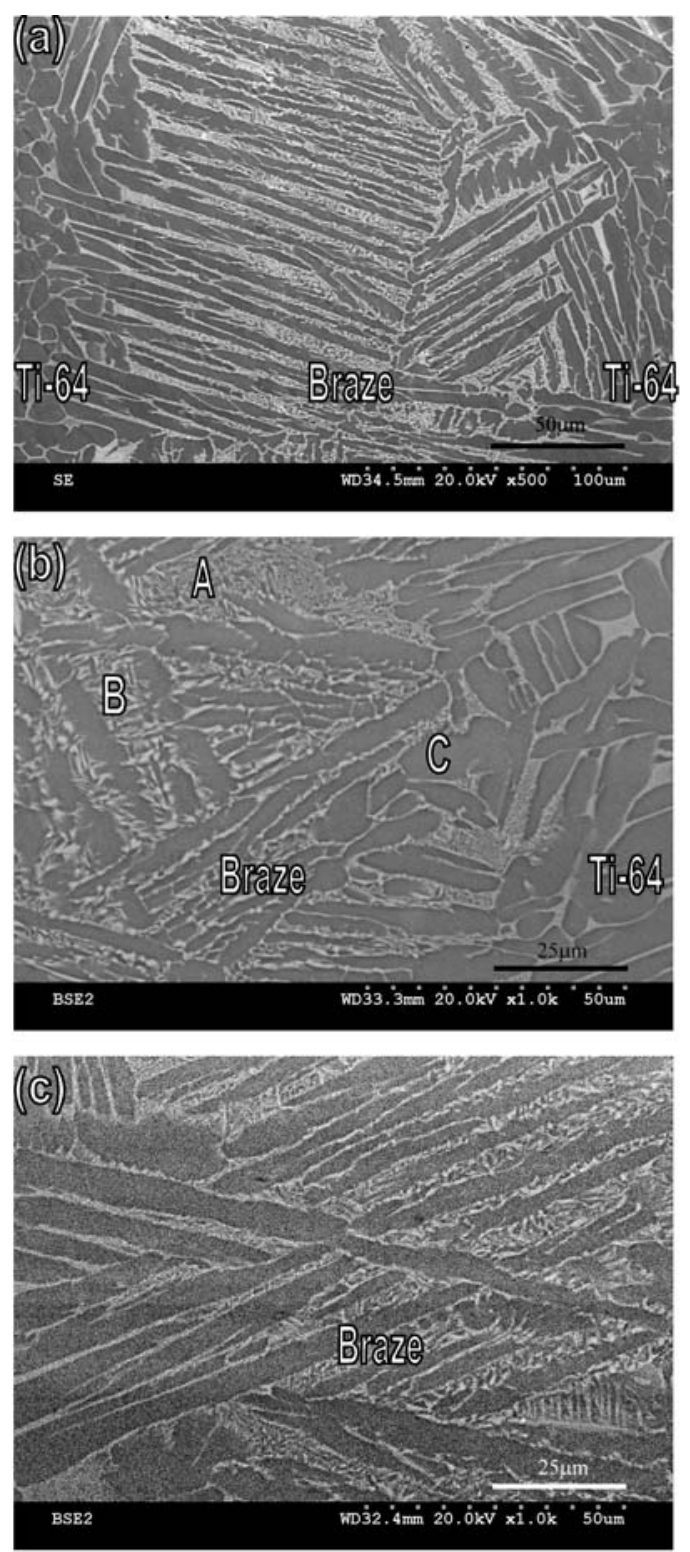

\begin{tabular}{cccccc}
\hline Location & $\mathrm{Al}$ & $\mathrm{Cu}$ & $\mathrm{Ni}$ & $\mathrm{Ti}$ & $\mathrm{V}$ \\
\hline $\mathrm{A}$ & 6.9 & 4.5 & 4.3 & 81.6 & 2.7 \\
$\mathrm{~B}$ & 5.6 & 4.0 & 4.8 & 80.6 & 5.0 \\
$\mathrm{C}$ & 8.9 & 1.1 & 0.3 & 88.9 & 0.8 \\
\hline
\end{tabular}

Figure 4 The SEM images and EDS chemical analyses of furnace brazed specimens at $970^{\circ} \mathrm{C}$ for (a) $1200 \mathrm{~s}$, SEI (b) $1200 \mathrm{~s}$, BEI and (c) $1800 \mathrm{~s}$, BEI. 

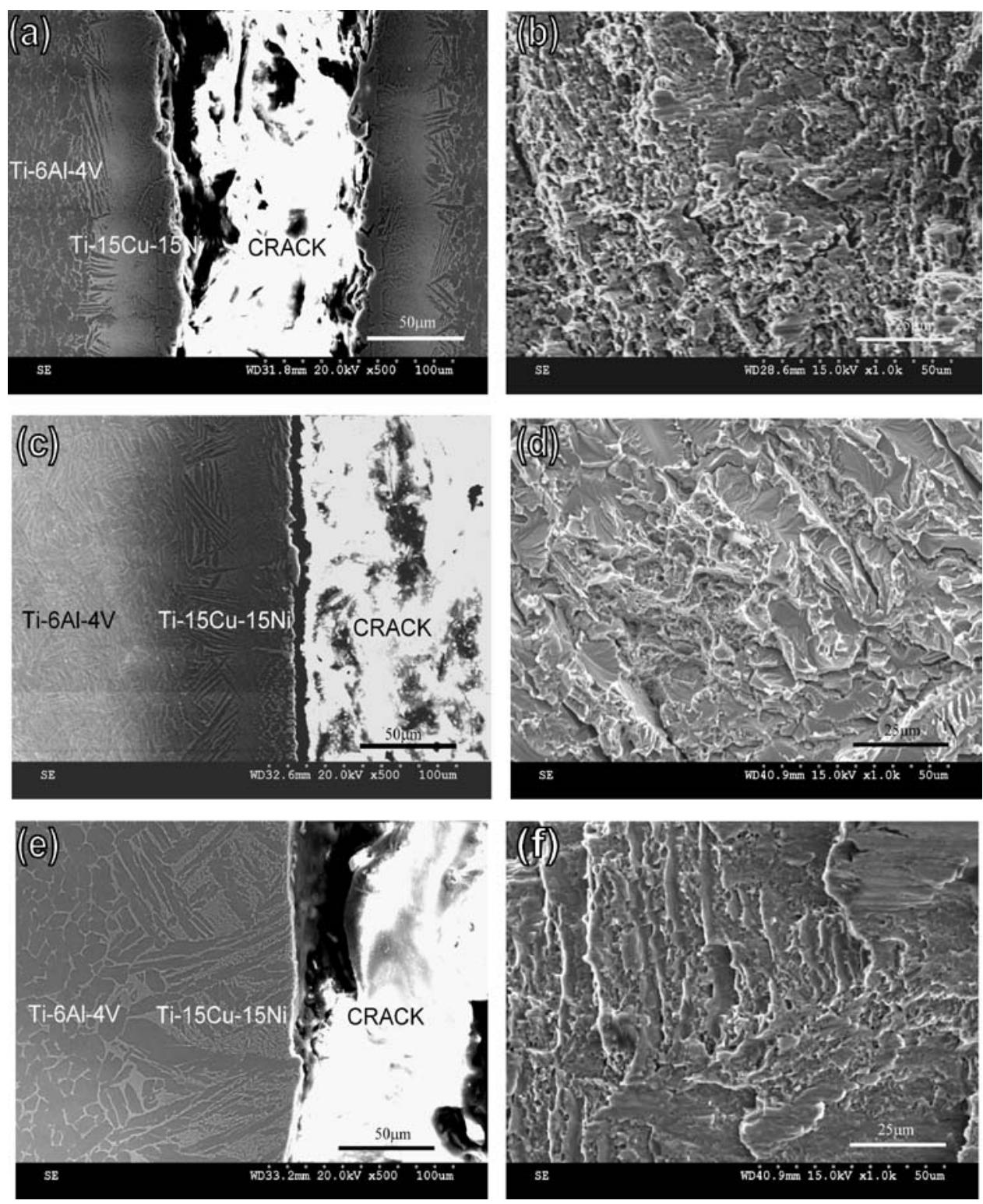

Figure 5 SEM cross-section images and fractographs of the brazed joint after shear test: (a, b) infrared brazing at $970^{\circ} \mathrm{C}$ for $180 \mathrm{~s}$; (c, d) infrared brazing at $1000^{\circ} \mathrm{C}$ for $180 \mathrm{~s}$; (e, f) furnace brazing at $970^{\circ} \mathrm{C}$ for $1200 \mathrm{~s}$.

ture with $\mathrm{Al}, \mathrm{Cu}, \mathrm{Ni}$, and $\mathrm{V}$ contents are observed in the furnace brazed joint [13]. As discussed earlier, the mass transport between molten braze and Ti-6Al-4V is significantly increased during furnace brazing because of its slow thermal cycle. It is also noted that the platelike $\alpha$ $\mathrm{Ti}$ (marked by $\mathrm{C}$ in Fig. 4) contains more $\mathrm{Al}$ and less $\mathrm{Cu}, \mathrm{Ni}$ as well as $\mathrm{V}$ than the eutectoid structure (marked by $\mathrm{A}$ and B in Fig. 4) [13]. Ti-6Al-4V is a type of $\alpha-\beta$ titanium alloy, and the microstructure of the $\alpha-\beta$ titanium alloy depends on the chemical composition of the alloy [1]. Aluminum is by far the most important substitutional element stabilizing the titanium $\alpha$-phase [1]. In contrast, copper, nickel and vanadium stabilize the $\beta$-phase titanium. It is consistent with the experimental observations.

Table I summarizes shear strengths of various (infrared) brazed specimens. Averaged shear strengths of (infrared) brazed joints are between 223 and $284 \mathrm{MPa}$. For the specimen infrared brazed at temperatures below $1000^{\circ} \mathrm{C}$ is fractured along the braze alloy in the shear test, but fracture of Ti-6Al-4V substrate is observed for all specimens infrared brazed at 1030 and $1060^{\circ} \mathrm{C}$. According to the experimental observation, erosion of the Ti-6Al-4V substrate becomes severe for the specimen infrared brazed above $1000^{\circ} \mathrm{C}$. Accordingly, the shear strength of Ti-6Al-4V substrate instead of the infrared brazed joint is measured in the shear test [10]. Fracture of the Ti-6Al-4V substrate is widely observed for the specimen infrared brazed at 1030 and $1060^{\circ} \mathrm{C}$. Since the shear strength of infrared brazed Ti-6Al-4V/Ti- $15 \mathrm{Cu}-$ $15 \mathrm{Ni} / \mathrm{Ti}-6 \mathrm{Al}-4 \mathrm{~V}$ joint cannot be accurately determined in the experiment, the shear strength of infrared brazed specimen above $1000^{\circ} \mathrm{C}$ is not included in Table I. Fig. 5a, c and e display SEM cross sections of the joints brazed 
at 970 and $1000^{\circ} \mathrm{C}$ after shear tests. Fig. $5 \mathrm{~b}$, d and $\mathrm{f}$ are fractographs of these brazed joints after shear tests. It is clear that fracture along the brazed joint is widely observed in the figure.

According to the experimental observations, Ti-6Al$4 \mathrm{~V}$ can be readily (infrared) brazed using the Ti$15 \mathrm{Cu}-15 \mathrm{Ni}$ as the brazing filler metal. Microstructural evolution of the (infrared) brazed joint with different brazing temperatures and time is studied. Minimum erosion of the base metal is obtained from the infrared brazed joint at $970{ }^{\circ} \mathrm{C}$ for $180 \mathrm{~s}$ due to its rapid thermal history.

\section{Acknowledgments}

The authors gratefully acknowledge the financial support of this research by the National Science Council (NSC), Republic of China under NSC grant 93-2216-E-002-028.

\section{References}

1. W. F. SMITH, in "Structure and Properties of Engineering Alloys" (McGarw-Hill Inc., New York, 1993) p. 433.
2. M. SCHWARTZ, in "Brazing: For the Engineering Technologist" (Chapman \& Hall, New York, 1995) p. 172.

3. D. L. OLSON, in "ASM Handbook" (ASM International, Ohio, 1993) Vol. 6.

4. G. HUMPSTON and D. M. JACOBSON, in "Principles of Soldering and Brazing" (ASM International, Ohio, 1993).

5. H. Y. CHAN, D. W. LIAW and R. K. SHIUE, Int. J. Refract. Met. Hard Mater. 22 (2004) 27.

6. R. K. SHIUE, S. K. WU and S. Y. CHEN, Intermetallics 11 (2003) 661.

7. C. L. OU and R. K. SHIUE, J. Mater. Sci. 38 (2003) 2337.

8. R. K. SHIUE, S. K. WU and S. Y. CHEN, Acta Mater. 51 (2003) 1991.

9. H. Y. CHAN and R. K. SHIUE, J. Mater. Sci.Lett. 22 (2003) 1659.

10. R. K. ShiUe, S. K. WU and C. H. CHAN, J. Alloy. Comp. 372 (2004) 148.

11. T. B. MASSALSKI, "Binary Alloy Phase Diagrams" (ASM International, Ohio, 1990).

12. P. VILlaRS, A. PRINCE and H. OKAMOTO, "Handbook of Ternary Alloy Phase Diagrams" (ASM International, Ohio, 1995).

13. S. KRISHNAMURTHY and F. H. FROES, Int. Mater. Rev. 34 (1989) 297.

Received 17 August 2004

and accepted 7 July 2005 